\title{
Kemampuan Tingkat Gender Siswa terhadap Hasil Belajar Matematika Kelas XII SMA Negeri 1 Ketapang Kalimantan Barat
}

\author{
Fitria Sari Hasanusi \\ Universitas Indraprasta PGRI \\ Email:Fitriasari253@gmail.com
}

\begin{abstract}
Abstrak
Tujuan penelitian, menganalisa hubungan antara kemampuan penalaran tingkat gender terhadap hasil belajar matematika siswa, Jenis penelitian kuantitatif. Populasi penelitian 98 siswa kelas XII SMA Negeri 1 Ketapang, Kalimantan Barat. Sampel penelitian 98 siswa berdasarkan pendapatan Arkunto. Teknik pengumpulan data data dengan angket dan dokumentasi. Teknik analisis data menggunakan analisis korelasi. Hasil penelitian diketahui 1) Tidak terdapat perbedaan kemampuan penalaran pembelajaran matematik, antara siswa laki-laki dengan siswa perempuan ditinjau dari hasil belajarnya, 2) Tidak terdapat hubungan antara kemampuan penalaran tingkat gender dalam pembelajaran matematika dengan hasil belajar siswa..
\end{abstract}

Kata Kunci : Gender, hasil belajar, Matematika

\section{PENDAHULUAN}

Gender merupakan perbedaan jenis kelamin yang bukan disebabkan oleh perbedaan biologis dan bukan kodrat Tuhan, proses sosial budaya yang panjang. Perbedaan perilaku antara laki-laki dan perempuan, selain disebabkan oleh faktor biologis sebagian besar justru terbentuk melalu proses sosial dan kultural. Gender bisa dikategorikan sebagai perangkat operasional dalam melakukan measure (pengukuran) terhadap persoalan laki-laki dan perempuan terutama yang terkait dengan pembagian peran dalam masyarakat yang dikonstruksi oleh masyarakat itu sendiri. Istilah gender telah menjadi isu penting dan sering diperbincangkan akhir-akhir ini. Banyak orang yang mempunyai persepsi bahwa gender selalu berkaitan dengan perempuan, sehingga setiap kegiatan yang bersifat perjuangan menuju kesetaraan dan keadilan gender hanya dilakukan dan diikuti oleh perempuan tanpa harus melibatkan laki-laki. Perempuan merupakan sumber daya yang jumlahnya cukup besar, bahkan di seluruh dunia melebihi jumlah laki-laki. Namun perempuan yang yang berpartisipasi di sektor publik berada jauh di bawah laki-laki, terutama di bidang politik. Rendahnya partisipasi perempuan di sektor publik bukan hanya terjadi di Indonesia, tetapi juga di seluruh dunia, termasuk juga di negara negara maju. Sebagai contoh dalam bidang pendidikan kaum perempuan masih tertinggal dibandingkan dengan lakilaki. Ketertinggalan perempuan tersebut tercermin dalam presentase perempuan buta huruf $(14,47 \%$ tahun 2001) yang lebih besar dibandingkan laki-laki (6,87\%). Data tersebut menegaskan bahwa partisipasi perempuan di sektor publik dalam bidang pendidikan masih 
rendah (Wirutomo, 2012:188-189). Contoh selanjutnya di India, di negara ini wanita dibagi menjadi tiga kelompok atau kelas, yaitu kelas atas, menengah, dan bawah. Pandangan masyarakat India terhadap wanita ditentukan pada kelas atau strata mana dia berada. Umumnya kelas atau strata tersebut dilihat dari kasta atau keturunan, selain itu juga dari kelas ekonomi. Tuntutan agar wanita terjun di dunia kerja mendorong mereka untuk memperoleh pendidikan yang lebih tinggi. Semakin tinggi pendidikan seorang wanita, semakin terangkat kelas dan derajat dia dalam masyarakat. Bagi kelas rendah, wanita dilahirkan, dirawat lalu tumbuh, harus tinggal dan bekerja di rumah., kemudian dikawinkan dalam usia belia. Artinya wanita yang tidak berpendidikan tidak mempunyai alasan untuk mencari pekerjaan yang lebih layak. Pendidikan dan penegakan hak-hak wanita mempunyai kaitan yang erat, semakin rendah pendidikan seorang wanita semakin sedikit kesempatan dia untuk menuntuk hak-haknya. Kendala utama datang dari pihak keluarga, wanita dianggap hanya pantas bekerja di dalam rumah saja. Oleh karena itu, kesempatan bagi mereka untuk berkiprah di luar rumah sangat terbatas. Keinginan untuk bersekolah atau mendapatkan pendidikan lainnya karena alasan untuk berkarir di luar rumah sangat sedikit yang mendapat persetujuan dari pihak keluarga khususnya orang tua (Bainar dan Halik,1999:37-38)

Kesetaraan gender merupakan suatu keadaan setara antara laki-laki dan perempuan dalam hak secara hukum dan kondisi atau kualitas hidupnya sama. Kesetaraan gender merupakan salah satu hak asasi setiap manusia. Gender itulah yang pembedaan peran, atribut, sifat, sikap dan perilaku yang tumbuh dan berkembang dalam masyarakat. Peran gender terbagi menjadi peran produktif, peran reproduksi serta peran sosial kemasyarakatan. Akan tetapi pada kenyataannya sampai saat ini, perempuan seringkali dianggap lemah dan hanya menjadi sosok pelengkap. Terlebih lagi adanya pola berpikir bahwa peran perempuan hanya sebatas bekerja di dapur, sumur, mengurus keluarga dan anak, sehingga pada akhirnya peran di luar itu menjadi tidak penting. Istilah kesetaraan gender sering terkait dengan istilah diskriminasi terhadap perempuan, subordinasi, penindasan, perilaku tidak adil dan semacamnya. Diskriminasi gender, menyebabkan kerentanan terhadap perempuan dan/atau anak perempuan serta berpotensi pada terjadinya kekerasan terhadap perempuan dalam berbagai bidang kehidupan. Oleh karena itu, banyak bermunculan program atau kegiatan, terutama dilakukan oleh beberapa LSM, untuk memperbaiki kondisi perempuan, yang biasanya berupa pelatihan tentang isu-isu gender, pembangkitan kesadaran perempuan, dan pemberdayaan perempuan dalam berbagai segi 
kehidupan ekonomi, sosial dan politik. Namun, hal ini justru berbanding terbalik dengan realita bahwa perempuan ternyata mempunyai peranan yang sangat besar dalam berbagai bidang, baik dalam bidang ekonomi, politik, maupun sosial, bahkan peranan perempuan justru sangat dirasakan oleh masyarakat luas (Megawangi, 1999:19).

Di dunia pendidikan, antara anak perempuan dan anak laki-laki hendaknya harus seimbang. Akan tetapi saat ini masih kerap terdapat adanya ketidakadilan gender. Banyak anak perempuan usia sekolah yang tak bisa lagi mendapatkan pendidikan yang layak. Hal ini disebabkan karena pengaruh cara pandang patriarkis dari orang tua mereka. Mereka beranggapan hal tersebut hanya menghambur-hamburan uang sebab mereka akan segera bersuami, peluang kerjanya kecil dan bisa lebih banyak membantu orang tua dalam pekerjaan rumah. Orang tua dari anak-anak perempuan usia sekolah dari keluarga miskin menganggap anak perempuan mereka tidak pantas untuk melanjutkan sekolah. Lebih baik langsung dinikahkan atau didorong bekerja sebagai pembantu rumah tangga atau buruh informal. Kurangnya pengetahuan dan asupan informasi membuat sebagian orang tua masih menganut paham tersebut. Berbeda halnya dengan anak laki-laki yang mendapat tempat istimewa baik segi pendidikan maupun kedudukan. Hal tersebut menyulut adanya ketimpangan antara budaya dan realita yang ada. Kesetaraan gender menjadi suatu program dan kegiatan yang diharapkan dapat meningkatkan derajat dan martabat perempuan. Al-Qur'an yang menjadi.

Matematika merupakan salah satu unsur penting dalam pendidikan . mata pelajaran matematika telah diperkenalkan kepada peserta didik sejak tingkat dasar sampai ke jenjang yang lebih tinggi, namun demikian kegunaan matematika bukan hanya memberikan kemampuan dalam perhitungan perhitungan kuantitatif tetapi juga dalam penataan cara berfikir terutama dalam pembentukan kemampuan menganalisis, membuat sistesis, melaku-kan evaluasi hingga kemampuan memecahkan masalah serta menerap-kannya pada kehidupan sehari hari. Salah satu arah Pengembangan pendidikan matematika salah satunya adalah untuk mengembangkan kemampuan bernalar logis peserta didik.

Kemudian Raharjo dalam Subagja, (2010:2) menyatakan, "Matematika diajarkan karena dapat menumbuh kembangkan kemampuan bernalar yaitu berpikir sistematis, logis dan kritis dalam mengkomunikasikan gagasan atau ide untuk memecahkan masalah “.

Kemampuan berpikir kreatif bagi siswa merupakan hal yang sangat penting dalam era persaingan global sekarang ini, karena tingkat kompleksitas permasalahan dalam segala aspek 
kehidupan sangat tinggi. Siswono (2008: 16) menjelaskan bahwa berpikir kreatif merupakan suatu kebiasaan dari pemikiran yang tajam dengan intuisi, menggerakkan imajinasi,m engungkapkan ide-ide baru, dan inspirasi ide-ide yang tidak terduga. Menurut Munandar dalam Irawan, (2015: 14), berpikir kreatif adalah aktivitas untuk melihat atau memikirkan sesuatu yang luar biasa, yang tidak lazim, memadukan informasi yang tampaknya tidak berhubungan dan mencetuskan suatu solusi atau gagasan baru yang menunjukan kelancaran (fluency), keluwesan (flexibility), orisinalitas (originality) dan elaboration. Silver (1997) menyatakan bahwa untuk menilai berpikir kreatif anak-anak dan orang dewasa menggunakan "The Torrance Tests of Creative Thinking (TTCT)”. Tiga kunci yang dinilai dalam kreativitas menggunakan TTCT adalah kefasihan (fluency)yaitu siswa mampu dalam menyelesaikan masalah dengan memberikan bermacam-macam jawaban, fleksibilitas (flexibility) yaitu siswa mampu dalam menyelesaikan masalah tidak hanya dengan satu cara tetapi bisa memberikan cara lain, dan kebaruan (novelty) yaitu siswa mampu menyelesikan suatu masalah dengan jawaban yang tidak biasa dilakukan oleh siswa lainnya.

Berpikir ilmiah secara kritis, dan mandiri merupakan salah satu tujuan dalam belajar matematika (Mendiknas, 2006). Maka dari itu, berpikir kritis menjadi hal yang penting dalam belajar matematika. Pentingnya berpikir kritis dalam pembelajaran matematika dipertegas oleh pemerintah dengan menetapkan penguasaan kemampuan kritis sebagai salah satu standar kelulusan matematika (Mendiknas, 2006). Dengan demikian, siswa yang berhasil belajar matematika diharapkan memiliki kemampuan berpikir kritis yang baik. Upaya Indonesia untuk meningkatkan kemampuan berpikir kritis belum berjalan dengan baik.

Menurut Siswono (2008: 31) bahwa tingkat kemampuan berpikir kreatif seseorang dapat dikelompokan menjadi 5 tingkatan. Tingkat ke-4 (sangat kreatif) yaitu siswa mampu menunjukkan aspek kefasihan, aspek fleksibilitas, dan aspek kebaruan dalam menyelesaikan suatu masalah, tingkat ke-3 (kreatif) yaitu siswa mampu menunjukkan aspek kefasihan dan aspek fleksibilitas atau aspek kefasihan dan kebaruan dalam menyelesaikan suatu masalah, tingkat ke-2 (cukup kreatif) yaitu siswa mampu menunjukkan aspek fleksibilitas atau aspek kebaruan dalam menyelesaikan suatu masalah, tingkat ke-1 (kurang kreatif) yaitu siswa hanya mampu menunjukkan aspek kefasihan dalam menyelesaikan suatu masalah, dan tingkat ke-0 (tidak kreatif) yaitu siswa tidak mampu menunjukkan ketiga aspek berpikir kreatif dalam menyelesaikan suatu masalah. 


\section{Kemampuan Matematika Laki dan Perempuan}

Kemampuan berpikir kreatif siswa dalam menyelesaikan suatu masalah antara siswa satu dengan yang lainnya tidak selalu sama. Nurmasari dkk (2014) melakukan penelitian dan mendapatkan hasil bahwa subjek laki-laki dapat memenuhi aspek kelancaran, keluwesan, keaslian, dan menilai, sedangkan subjek perempuan dapat memenuhi aspek kelancaran, keluwesan, keaslian. Menurut Fakih (2006: 71), gender merupakan suatu sifat yang melekat pada kaum laki-laki maupun perempuan yang dikontruksikan secara sosial maupun kultural. Suhapti (1995) mengartikan gender adalah perbedaan peran antara perempuan dan laki-laki yang mengakibatkan perbedaan perlakuan antara perempuan dan laki-laki di masyarakat. Perbedaan gender tentu akan menyebabkan perbedaan fisiologi dan mempengaruhi perbedaan psikologis dalam belajar, sehingga siswa laki-laki dan siswa perempuan memiliki perbedaan dalam mempelajari matematika.

Kemampuan atau kecakapan dapat dibagi kedalam dua bagian yaitu kecakapan nyata (actual ability) dan kecakapan potensial (potential ability). Kecakapan nyata (actual ability) yaitu kecakapan yang diperoleh melalui belajar (achivemen $t$ atau prestasi), yang dapat segera didemonstrasi-kan dan diuji sekarang. Misalkan, setelah selesai mengikuti proses pembelajaran (kegiatan tatap muka di kelas), pada akhir pembelajaran siswa diuji oleh guru tentang materi yang disampaikan-nya (tesformatif). Ketika siswa mampu menjawab dengan baik tentang pertanyaan guru, maka kemampuan tersebut merupakan kecakapan nyata (chievement). Sedangkan kecakapan potensial merupakan aspek kecakapan yang masih terkandung dalam diri individu dan diperoleh dari faktor keturunan (herediter). Kecakapan potensial dapat dibagi ke dalam dua bagian yaitu kecakapan dasar umum (Inteligensi atau kecerdasan) dan kecakapan dasar khusus (bakat atau aptitudes).

Krutetski dalam Nafi'an (2011), menjelaskan perbedaan antara laki-laki dan perempuan dalam belajar matematika sebagai berikut: 1) Laki-laki lebih unggul dalam penalaran, perempuan lebih unggul dalam ketepatan, ketelitian, kecermatan, dan keseksamaan berpikir. 2) Laki-laki memiliki kemampuan matematika dan mekanika yang lebih baik dari pada perempuan, perbedaan ini tidak nyata pada tingkat sekolah dasar akan tetapi menjadi tampak lebih jelas pada tingkat yang lebih tinggi. Pendapat tersebut menunjukkan kemampuan yang tinggi bagi anak laki-laki dalam hal matematika, namun perempuan lebih unggul dalam aspek efektifnya (tekun, teliti, cermat). Sementara Maccoby dan Jacklyn (1974) mengatakan laki-laki dan perempuan 
mempunyai perbedaan kemampuan antara lain sebagai berikut: 1) Perempuan mempunyai kemampuan verbal lebih tinggi daripada laki-laki. 2) Laki-laki lebih unggul dalam kemam-puan visual spatial (penglihatan keruangan) daripada perempuan. 3) laki-laki lebih unggul dalam emampuan matematika. Menurut American Psychological Association (Science Daily, 6 Januari 2010) (yang dikutip oleh Lestari dalam Nafi'an (2011), mengemukakan berdasarkan analisis terbaru dari penelitian internasional kemampuan perempuan diseluruh dunia dalam atematika tidak lebih buruk daripada kemampuan laki-laki meskipun laki-laki memiliki kepercayaan diri yang lebih dari perempuan dalam matematika, dan perempuan-perempuan dari negara dimana kesamaan gender telah diakui menunjukkan kemampuan yang lebih baik dalam tes matematika.

\section{METODE}

Metode penelitian yang digunakan dalam penelitian ini adalah metode survei yang bersifat eksplanatif asosiatif. Jenis survei ini digunakan untuk mengetahui suatu kondisi tertentu terjadi atau apa yang mempengaruhi terjadinya suatu kondisi. Tingkat Eksplanasi adalah tingkat penjelasan, yaitu bagaimana variabel-variabel yang diteliti itu akan menjelaskan obyek yang diteliti melalui data yang terkumpul (Sugiyono, 2006:6). Survei eksplanatif dalam penelitian ini dibagi menjadi dua bagian, yaitu: 1) Komparatif yaitu survei yang bertujuan untuk membuat komparasi (membandingkan) antara variabel yang satu dengan variabel lainnya yang sejenis; 2) Asosiatif, yaitu survei bersifat asosiatif adalah untuk menjelaskan hubungan (korelasi) antar variabel.

Populasi penelitian ini adalah seluruh siswa kelas XII SMA NEGERI 1 Ketapang Kalimantan Barat tahun pelajaran 2016/2017 dengan siswa sebanyak 98 siswa yang terdistribusi pada 3 kelas. Pengambilan sampel dilakukan dengan mengambil satu kelas secara acak dengan pertimbangan setiap kelas memiliki kemampuan berfikir pemecahan masalah matematis yang relatif sama dan diperoleh dari siswa perempuan di kelas XII SMA Negeri 1 Ketapang dengan jumlah siswa perempuan sebanyak 49 siswa dan 49 siswa laki-laki sebagai sampel penelitian. Mengenai prosedur penelitian, dimulai dengan pemberian angket kemampuan dan hasil belajar matematika. Setelah data kemampuan terkumpul, data tersebut dikelompokkan berdasarkan kecende-rungan hasil belajar siswa dan tingkat kemandirian belajarnya (tinggi, sedang, dan rendah). Analisis data untuk mengetahui perbedaan kemampuan berpikir berdasarkan kemampuan berpikir laki-laki dan perempuan. Penelitian ini bertujuan untuk mengetahui 
gambaran kemampuan belajar matematika siswa laki-laki dan siswa perempuan, serta pengaruh terhadap hasil belajarnya.

\section{HASIL PENELITIAN}

Distribusi responden berdasarkan hasil kuesioner dan wawancara dari total responden sebanyak 98 responden. Responden dalam penelitian ini adalah Siswa Kelas XII SMA Negeri 1 Ketapang, Kalimantan Barat, yang berjumlah 98 siswa yang disajikan pada tabel di bawah ini:

Tabel 1

Jumlah Siswa Yang Menjadi Sampel

\begin{tabular}{|c|l|c|c|}
\hline \multicolumn{2}{|c|}{} & Frequency & Percent \\
\hline \multirow{3}{*}{ Valid } & Laki-laki & 49 & 50,0 \\
\cline { 2 - 4 } & Perempuan & 49 & 50,0 \\
\cline { 2 - 4 } & Total & 98 & 100,0 \\
\hline
\end{tabular}

Berdasarkan pada tabel 1 di atas,

Dari 98 sampel penelitian bahwa siswa yang memiliki jenis kelamin perempuan sebanyak 49 responden (50\%). Sementara sisanya sebanyak 49 siswa (50\%) adalah siswa laki-laki. Hasil data kemampuan dan hasil belajar dianalisis untuk mengetahui kemampuan penalaran matematika dan hasil belajar peserta didik. Tahap pertama yang dilakukan adalah analisis deskriptif data, dengan hasil seperti yang tercantum dalam tabel berikut;

Tabel 2

\section{Statistik Deskriptif Kemampuan dan Hasil Belajar Siswa Kelas XII SMA Negeri Ketapang}

\begin{tabular}{|c|c|c|c|}
\hline & & Statistics & \\
\hline & & $\begin{array}{c}\text { Kemampuan } \\
\text { nalar siswa }\end{array}$ & $\begin{array}{c}\text { Hasil Belajar } \\
\text { Siswa }\end{array}$ \\
\hline & Valid & 98 & 98 \\
\hline & Missing & 0 & 0 \\
\hline $\mathrm{Me}$ & & 75,8163 & 77,0612 \\
\hline Std & rror of Mean & ,75973 & ,64066 \\
\hline $\mathrm{Me}$ & & 75,0000 & 77,0000 \\
\hline$\overline{\mathrm{Std}}$ & eviation & 7,52089 & 6,34216 \\
\hline
\end{tabular}




\begin{tabular}{|l|r|r|}
\hline Variance & 56,564 & 40,223 \\
\hline Range & 38,00 & 45,00 \\
\hline Minimum & 58,00 & 50,00 \\
\hline Maximum & 96,00 & 95,00 \\
\hline
\end{tabular}

Dari tabel di atas, terlihat bahwa rata-rata kemampuan nalar siswa 75,81 dan hasil belajar siswa 77,06. Nilai maksimum kemampuan nalar siswa adalah sebesar 96 dan minimum sebesar 58. Sedangkan nilai maksimum hasil belajar siswa adalah sebesar 95 dan minimum sebesar 50 .

Untuk melihat perbedaan rerata hasil pretes ketiga kelas ini signifikan atau tidak maka dilakukan uji statistik menggunakan SPSS 21.0, dengan tahapan-tahapan sebagai berikut:

\section{Uji Normalitas Data}

Tabel 3

Hasil Uji Normalitas Data

\begin{tabular}{|l|l|r|r|}
\hline \multicolumn{3}{|c|}{ One-Sample Kolmogorov-Smirnov Test } \\
\hline \multicolumn{2}{|l|}{} & $\begin{array}{r}\text { Kemampuan } \\
\text { nalar siswa }\end{array}$ & $\begin{array}{r}\text { Hasil } \\
\text { Belajar } \\
\text { Siswa }\end{array}$ \\
\hline N & Mean & 75,8163 & 77,0612 \\
\hline \multirow{2}{*}{$\begin{array}{l}\text { Normal } \\
\text { Parameters }\end{array}$} & $\begin{array}{l}\text { Std. } \\
\text { Most Extreme }\end{array}$ & 7,52089 & 6,34216 \\
\hline Differences & Absolute &, 074 &, 158 \\
\cline { 2 - 4 } & Positive &, 074 &, 158 \\
\cline { 2 - 4 } & Negative &,- 057 &,- 117 \\
\hline Kolmogorov-Smirnov Z &, 731 & 1,567 \\
\hline Asymp. Sig. (2-tailed) &, 659 &, 015 \\
\hline \multicolumn{2}{|l|}{ a. Test distribution is Normal. } \\
\hline b. Calculated from data. & \\
\hline
\end{tabular}

\section{Hubungan Antara Kemampuan Nalar dengan Hasil Belajar Matematika Siswa}

Analisis yang digunakan untuk hubungan antara Kemampuan Nalar dengan Hasil Belajar Matematika Siswa Kelas XII SMA Neegeri 1 Ketapang, Kalimantan Barat adalah korelasi Chi square. Kemudian di uji signifikansi korelasi dari setiap perhitungan antara variabel bebas dengan variabel terikat. 
Berikut adalah hipotesis perhitungan statistik inferensial untuk melihat korelasi antara Kemampuan Nalar dengan Hasil Belajar Matematika Siswa Kelas XII SMA Neegeri 1 Ketapang, Kalimantan Barat adalah :

$\mathrm{H}_{0}: \rho=0$ (Tidak terdapat hubungan antara Kemampuan Nalar dengan Hasil Belajar Matematika Siswa Kelas XII SMA Neegeri 1 Ketapang, Kalimantan Barat $\mathrm{H}_{1}: \rho \neq 0$ (Terdapat hubungan antara antara Kemampuan Nalar dengan Hasil Belajar Matematika Siswa Kelas XII SMA Negeri 1 Ketapang, Kalimantan Barat $\alpha=0.05$

Berdasarkan hasil penelitian didapatkan hubungan antara Kemampuan Nalar dengan Hasil Belajar Matematika Siswa Kelas XII SMA Negeri 1 Ketapang, Kalimantan Barat dapat dilihat pada tabel

4, diketahui dari 98 responden menunjukkan bahwa kemampuan penalaran siswa laki-laki pada pelajaran matematika sebanyak $2(2,7 \%)$ kurang baik, sebanyak $23(20,5 \%)$ baik dan sebanyak $8(9,8 \%)$ adalah sangat baik. Sedangkan kemampuan penalaran siswa perempuan sebanyak $6(5,3 \%)$ kurang baik, sebanyak 38 (40,5\%) baik dan sebanyak $21(19,2 \%)$ sangat baik.

Tabel 4

Hasil Uji Hubungan Antara Kemampuan Nalar dengan Hasil Belajar Matematika

\begin{tabular}{|c|c|c|c|c|c|c|}
\hline \multicolumn{7}{|c|}{ Hasil Belajar * Kemampuan Nalar Crosstabulation } \\
\hline & & & \multicolumn{3}{|c|}{ Kemampuan Nalar } & \multirow[t]{2}{*}{ Total } \\
\hline & & & Kurang baik & Baik & Sangat Baik & \\
\hline \multirow{10}{*}{ Hasil Belajar } & \multirow{5}{*}{ Laki-laki } & Count & 2 & 23 & 8 & 33 \\
\hline & & Expected Count & 2,7 & 20,5 & 9,8 & 33,0 \\
\hline & & $\%$ within Hasil Belajar & $6,1 \%$ & $69,7 \%$ & $24,2 \%$ & $100,0 \%$ \\
\hline & & $\%$ within Kemampuan & $25,0 \%$ & $37,7 \%$ & $27,6 \%$ & $33,7 \%$ \\
\hline & & $\%$ of Total & $2,0 \%$ & $23,5 \%$ & $8,2 \%$ & $33,7 \%$ \\
\hline & \multirow{5}{*}{ Perempuan } & Count & 6 & 38 & 21 & 65 \\
\hline & & Expected Count & 5,3 & 40,5 & 19,2 & 65,0 \\
\hline & & $\%$ within Hasil Belajar & $9,2 \%$ & $58,5 \%$ & $32,3 \%$ & $100,0 \%$ \\
\hline & & $\%$ within Kemampuan & $75,0 \%$ & $62,3 \%$ & $72,4 \%$ & $66,3 \%$ \\
\hline & & $\%$ of Total & $6,1 \%$ & $38,8 \%$ & $21,4 \%$ & $66,3 \%$ \\
\hline \multirow{2}{*}{\multicolumn{2}{|c|}{ Total }} & Count & 8 & 61 & 29 & 98 \\
\hline & & Expected Count & 8,0 & 61,0 & 29,0 & 98,0 \\
\hline
\end{tabular}




\begin{tabular}{|l|l|r|r|r|r|}
\hline \multirow{2}{*}{} & $\%$ within Hasil Belajar & $8,2 \%$ & $62,2 \%$ & $29,6 \%$ & $100,0 \%$ \\
\cline { 2 - 6 } & $\%$ within Kemampuan & $100,0 \%$ & $100,0 \%$ & $100,0 \%$ & $100,0 \%$ \\
\cline { 2 - 6 } & $\%$ of Total & $8,2 \%$ & $62,2 \%$ & $29,6 \%$ & $100,0 \%$ \\
\hline
\end{tabular}

Hasil uji statistik dengan uji korelasi Chi Square pada alpha 5\% atau 0,05 didapatkan nilai $p$-value $(1,194)$ atau $1,194>0,05$ yang artinya tidak ada hubungan antara hubungan antara Kemampuan Nalar dengan Hasil Belajar Matematika Siswa Kelas XII SMA Negeri 1 Ketapang, Kalimantan Barat

\begin{tabular}{|l|r|r|r|}
\hline \multicolumn{3}{|c|}{ Chi-Square Tests } \\
\hline & \multicolumn{1}{|c|}{ Value } & df & $\begin{array}{c}\text { Asymp. Sig. } \\
\text { (2-sided) }\end{array}$ \\
\hline Pearson Chi-Square & $1,194^{\text {a }}$ & 2 &, 550 \\
\hline Likelihood Ratio & 1,217 & 2 &, 544 \\
\hline $\begin{array}{l}\text { Linear-by-Linear } \\
\text { Association }\end{array}$ &, 157 & 1 &, 692 \\
\hline N of Valid Cases & 98 & & \\
\hline $\begin{array}{l}\text { a. 1 cells (16,7\%) have expected count less than 5. The } \\
\text { minimum expected count is 2,69. }\end{array}$
\end{tabular}

$\cdot$

3. Tabel 6. Perbedaan Hasil Belajar Siswa Laki dengan Perermpuan di Kelas IV SMA Negeri 1 Ketapang

\begin{tabular}{|c|l|c|c|c|}
\hline \multicolumn{2}{|c|}{} & \multicolumn{2}{c|}{ Jenis Kelamin } & \multirow{2}{*}{ Total } \\
\cline { 2 - 5 } \multicolumn{2}{|c|}{} & Laki-laki & Perempuan & 33 \\
\hline $\begin{array}{c}\text { Hasil } \\
\text { Belajar }\end{array}$ & Laki-laki & 15 & 18 & 65 \\
\cline { 2 - 5 } & Perempuan & 34 & 31 & 98 \\
\hline Total & 49 & 49 & \\
\hline
\end{tabular}

Berdasarkan tabel 6 dapat diketahui dari 98 responden menunjukkan bahwa hasil belajar siswa laki-laki berbeda dengan hasil belajar perempuan. Hasil belajar siswa perempuan memiliki nilai lebih tinggi dari hasil belajar siswa laki-laki yaitu sebanyak 65 siswa. Sedangkan siswa lakilaki memiliki nilai rendah sebanyak 33 siswa.

Hasil uji statistik dengan uji korelasi Chi Square pada alpha 5\% atau 0,05 didapatkan nilai $p$-value $(0,411)$ atau $0,411>0,05$ yang artinya tidak ada perbedaan yang signifikan antara hasil belajar siswa perempuan dengan hasil belajar siswa laki-laki. 


\section{PEMBAHASAN}

Berdasarkan tabel 7 berikut, maka dapat diketahui bahwa besar responden sebanyak 98 siswa Kelas XII SMA Negeri 1 Ketapang Kalimantan Barat, yang terdiri dari frekuensi siswa laki-laki sebanya 49 (50\%) dan siswa perempuan sebanyak 49 (50\%).

Dari hasil analisis data statistik diketahui bahwa nilai p-value $(1.194>\alpha 0,05)$, karena hasil sign. 1,194 lebih besar daripada $\alpha$ 0,050 maka dapat diartikan tidak ada hubungan yang signifikan antara kemampuan nalar dalam pembelajaran matematika dengn hasil belajar siswa.

Analisa Hubungan Antara Kemampuann Penalaran dalam pembelajaran mate-matika

Untuk menganalisis hubungan antara Kemampuann Penalaran dalam pembelajaran matematika dengan hasil belajar digunakan korelasi Chi square. Penelitian ini menguji hipotesis null bahwa terdapat hubungan antara Kemampuann Penalaran dalam pembelajaran matematika dengan hasil belajar (dengan alpha 5\%).

Berdasarkan uji statistik korelasi Chi square didapatkan nilai p-value yaitu sebesar 1,194. Hasil ini menunjukkan bahwa p-value < alpha yang mengakibatkan $\mathrm{H}_{0}$ diterima dan $\mathrm{H}_{1}$ ditolak. Hal ini berarti tidak terdapat hubungan yang bermakna antara Kemampuan Penalaran dalam pembelajaran matematika dengan hasil belajar ssiwa Kelas XII SMA Negeri 1 Ketapang, Kalimantan Barat, tahun ajaran 2017/2018.

\section{SIMPULAN}

Dari hasil penelitian terungkap bahwa tidak terdapat perbedaan kemampuan penalaran pembelajaran matematik, antara siswa laki-laki dengan siswa perempuan ditinjau dari hasil belajarnya. Tidak terdapat hubungan antara kemampuan penalaran dalam pembelajaran matematika dengan hasil belajar siswa. Dari hasil penelitian tersebut menunjukkan bahwa setiap siswa, baik siswa laki-laki maupun siswa perempuan mempunyai kemampuan penalaran dalam pembelajaran matematik yang sama. 


\section{DAFTAR PUSTAKA}

Fakih, Mansour, (2008), Analisis Gender dan Transformasi Sosial, Yogyakarta: INSIST Press

Munandar, S.C. Utami. (2012). Pengem-bangan Kreativitas Anak Berbakat. Rineka Cipta. Jakarta

Siswono. 2008. Model Pembelajaran Matematika Berbasis pengajuan dan Pemecahan Masalah untuk meningkatkan kemampuan berpikir kreatif. Surabaya: Unesa University Press.

Subagja, S. (2010), Penggunaan Pembela-jaran Probing-Prompting dalam Upay Meningkatkan Kemampuan Penalaran Matematika Siswa SMP. Pendidikan Matematika FKIP UNPAS. Bandung: Tidak diterbitkan

Sugiyono. (2006), Metode Penelitian Kuantitatif, Kualitatif dan R \&. D. Bandung:Alfabeta.

Widiyarto, S. (2018). Pengaruh Metode Cooperative Scrift dan Peran Orang Tua Terhadap Prestasi Belajar Bahasa Indonesia. Khazanah Pendidikan, 11(1).

Widiyarto, S. (2017). Penggunaan Pembelajaran Pemberian Tugas (Foxfire) untuk Meningkatkan Keterampilan Menulis Eksposisi. Deiksis: Jurnal Pendidikan Bahasa Dan Sastra Indonesia, 4(1). 
